\title{
Langtidsvirkende naltrekson - en ny vei ut av opiatavhengighet?
}

\author{
Langtidsvirkende naltrekson (opioidantagonist) i injeksjonsform kan kanskje bidra til å redusere antall \\ overdoser og gi redusert tilbakefallsrate hos opiatavhengige. Medikamentet utprøves nå i en multisenter- \\ studie, og om utfallet av studien er positivt, vil legemiddelassistert avholdenhet kunne vurderes som behand- \\ lingsalternativ for opiatavhengige i Norge.
}

Norge er blant landene i Europa med best utbygd tilbud innen substitusjonsbehandling for opiatavhengige, med over halvparten av registrerte brukere innlemmet i legemiddelassistert rehabilitering (LAR) (1). Behandling med metadon, senere subutex og suboxone, har vist å halvere illegal opiatbruk og overdosedødelighet (2, 3). Ulempen ved slik substitusjonsbehandling er at metadon og buprenorfin er avhengighetsskapende opiate legemidler og har stor gateverdi. I dag er førstevalg en kombinasjon av buprenorfin og nalokson (opioidreseptorantagonist) for å forhindre overdose ved injisering av medikamentet (4).

Langtidsvirkende naltrekson, en opioidreseptorantagonist gitt som intramuskulær injeksjon, er en type medikamentell behandling som foreløpig ikke er i bruk i Europa. Behandlingen representerer et nytt konsept som går i samme hovedretning som dagens LAR-behandling, det vil si legemiddelassistanse for å ivareta avhold fra opiater og illegale rusmidler.

\section{Naltrekson}

Naltrekson er en syntetisk opioidantagonist (5) med tilnærmet full antagonistisk effekt på $\mu$-reseptorene i hjernen. Medikamentet hindrer heroin og opiater tilgang til reseptorene. Dermed utløses ingen ruseffekt, og muligheten for overdose blokkeres. Dette er et viktig poeng for pasienter med særlig høy overdoserisiko, slik som pasienter nylig utskrevet fra avgiftning, tverrfaglig spesialisert rusbehandling eller fengsel (6). Langtidsvirkende naltrekson har fire ukers virketid og vil derfor beskytte mot muligheten for å overdosere på opiater selv om deltakeren skulle gå på en «sprekk». Naltrekson har høy reseptoraffinitet og fortrenger agonister med lavere reseptoraffinitet, som heroin, morfin og metadon. For ikke å utløse kraftige abstinensreaksjoner må derfor pasienten være helt avgiftet fra opiater før man introduserer naltrekson. Naltrekson er ikke et avhengighetsskapende medikament og utløser ikke abstinensreaksjon ved seponering (7).

Naltreksontabletter kan gi milde til moderate bivirkninger. I oppstartsfasen er lettere hodepine, kvalme/oppkast og ubehag i ledd og muskler hyppigst beskrevet (8). Langtidsvirkende naltrekson har foreløpig vist å ha mindre bivirkninger enn naltrek- sontabletter (7). Studier på langtidsvirkende naltrekson har ikke vist risiko for leveraffeksjon ved normaldosering (9). Ved behandling med langtidsvirkende naltrekson vil opiatbaserte analgetika ha redusert virkning, og andre typer legemidler må

\section{«Legemiddelassistert avholdenhet kan bli \\ en mulig vei ut av opiat- avhengighet for mange pasienter»}

benyttes ved smerter, f.eks. ikke-steroide antiinflammatoriske midler (NSAID), regional blokade eller ketamin. Det er mulig å overkomme naltrekson med opiater, men det krever så høye doser at det kun må gjøres på sykehus med beredskap til å sikre adekvat sirkulasjon.

\section{Et nytt behandlingsprinsipp}

Tidligere studier på langtidsvirkende naltrekson har vist at opiatbruken reduseres drastisk (10-11). Ved Senter for rus- og avhengighetsforskning, Universitetet i Oslo gjør vi nå en multisenterstudie der vi sammenlikner langtidsvirkende naltreksoninjeksjon og buprenorfin-/naloksontabletter. Målet er å finne ut hvorvidt langtidsvirkende naltrekson kan være et godt behandlingsalternativ for pasienter med erkjent opiatavhengighet.

I studien randomiseres pasientene til intramuskulær naltrekson hver 28. dag eller daglig buprenorfin-/naloksontabletter i 12 uker. Deretter følger 36 uker der pasienten selv kan velge mellom buprenorfin/ nalokson eller intramuskulær naltrekson. Deltakerne følges opp med ukentlige urinprøver og månedlige intervjuer. Inklusjonskriterier er opiatavhengighet, at pasienten har vedtak om LAR-behandling eller søkes til behandlingstilbudet før inklusjon i studien. Gravide eller ammende kvinner og personer med alvorlig somatisk eller psykisk sykdom ekskluderes.

Så langt synes hovedmotivasjonen for å delta i studien å være muligheten for å få naltreksoninjeksjon. Interessen for studien oppleves som økende både blant helsepersonell og opiatavhengige. Visjonen om økt autonomi og medikamentstøttet rusfrihet synes å virke fristende for mange opiatavhengige, men ambivalensen er også betydelig og flere ønsker å vente til andre i miljøet kan gi positiv tilbakemelding om effekten. Videre kan det være et vanskelig valg å blokkere muligheten for å kunne ruse seg på opiater.

Dersom utfallet av studien viser at langtidstidsvirkende naltreksoninjeksjoner kan redusere antall overdoser og gi redusert tilbakefallsrate, vil injeksjoner med langtidsvirkende naltrekson kunne bli implementert som et nytt behandlingsalternativ for opiatavhengige i Norge. Legemiddelassistert avholdenhet kan bli en mulig vei ut av opiatavhengighet for mange pasienter.

\section{Live Sanderud Stavseth \\ l.s.stavseth@medisin.uio.no \\ Nikolai Kunøe \\ Lars Tanum}

Live Sanderud Stavseth (f. 1978) er lege i spesialisering i psykiatri og har permisjon fra stilling ved Lovisenberg Diakonale Sykehus. Hun er stipendiat og ph.d.-kandidat ved Senter for rusog avhengighetsforskning, Universitetet i Oslo. Forfatter har fylt ut ICMJE-skjemaet og oppgir ingen interessekonflikter.

Nikolaj Kunøe (f. 1976) er cand.psychol. og postdoktor ved Senter for rus- og avhengighetsforskning, Universitetet i Oslo. Han har jobbet som klinisk psykolog ved psykiatrisk ungdomsteam. Ph.d.-avhandlingen omhandlet naltreksonbehandling.

Forfatter har fylt ut ICMJE-skjemaet og oppgir ingen interessekonflikter.

Lars Tanum (f. 1956) er dr.med, spesialist i psykiatri og i klinisk farmakologi, seksjonssjef for forskning ved FoU-avdeling psykisk helsevern, Akershus universitetssykehus og professor II ved Universitetet i Oslo.

Forfatter har fylt ut ICMJE-skjemaet og oppgir ingen interessekonflikter. 


\section{Litteratur}

1. Europeisk overvåkingssenter for narkotika og narkotikamisbruk. Europeisk narkotikarapport 2013: Trender og utvikling. Luxembourg: Den europeiske unions publikasjonskontor, 2013.

2. Clausen T, Anchersen K. Waal H. Mortality prior to, during and after opioid maintenance treatment (OMT): a national prospective cross-registry study. Drug Alcohol Depend 2008; 94: 151 -7.

3. Lauritzen G, Ravndal E, Larsson J. Gjennom 10 år. En oppfølgingsstudie av narkotikabrukere i behandling. SIRUS-rapport nr. 6/2012. Oslo: Statens institutt for rusmiddelforskning, 2012

4. Nasjonal retningslinje for legemiddelassistert rehabilitering ved opioidavhengighet. Oslo: Helsedirektoratet, 2011.

5. Blumberg H, Pachter IJ, Matossian Z. 14hydroxydihydronormorphinone derivatives. U.S. Patent 1967: 332: 950.
6. Ravndal E, Amundsen EJ. Mortality among drug users after discharge from inpatient treatment: an 8-year prospective study. Drug Alcohol Depend 2010; 108: 65-9.

7. Krupitsky E, Nunes EV, Ling W et al. Injectable extended-release naltrexone for opioid dependence: a double-blind, placebo-controlled, multicentre randomised trial. Lancet $2011 ; 377$ : $1506-13$.

8. Psychopharmacological drugs advisory commitee meeting. Vivitrol Inaltrexone for extended-release injectable suspension). Silver Spring, MD: FDA, 2010.

9. Mitchell MC, Memisoglu A, Silverman BL. Hepatic safety of injectable extended-release naltrexone in patients with chronic hepatitis $\mathrm{C}$ and HIV infection. J Stud Alcohol Drugs 2012; 73: $991-7$.

10. Kunøe N, Lobmaier P, Vederhus JK et al. Naltrexone implants after in-patient treatment for opioid dependence: randomised controlled trial. Br J Psychiatry 2009; 194: 541-6.

11. Kunøe N, Lobmaier P, Vederhus JK et al. Challenges to antagonist blockade during sustainedrelease naltrexone treatment. Addiction 2010; 105 : 1633-9.

Mottatt 4.9. 2013, første revisjon innsendt 1.10. 2013, godkjent 8.10. 2013. Redaktør Hanne Støre Valeur.

\section{Publisert først på nett.}

